\title{
BAZA DIGITALNIH PODATKOV RELIEFA - NOVE MOŽNOSTI 3D MODELIRANJA RELIEFA
}

\author{
Mateja Rihtaršič
}

\section{Izvleček}

UDK 528.9:681.3

Tudi na področje digitalnega modeliranja reliefa so GIS prinesli vrsto sprememb. Sodobni DMR morajo biti zgrajeni $v$ obliki pravih relacijskih podatkounih baz $z$ visoko stopnjo "inteligence". $V$ članku so predstavljene osnovne zahteve, ki jih morajo izpolnjevati takšne podatkoune baze, skupaj z osnounimi koraki, ki so potrebni za njihovo vzpostavitev. Izpostavljeni so problemi, vezani na regionalni nivo, večnamensko uporabo, nove možnosti in neposredno združitev $v$ GIS. Na osnovi praktičnega modela, ki je bil vzpostavljen preko manjšega testnega območja, so podane tudi nekatere praktične izkušnje.

UDC 528.9:681.3

\section{Abstract}

DIGITAL TERRAIN DATA BASE - NEW POSSIBILITIES OF 3D TERRAIN MODELING

GISs has brought new dimensions in the field of digital terrain modelling, too. Modern DTMs must be real (relational) databases with high degree of "intelligence". This paper presents some of the demands, which have to be solved in modern digital terrain databases, together with main steps of their's generation. Problems, connected to regional level, multi-purpose use, new possibilities and direct integration into GIS are presented. The practical model was created across smaller test area, so few lines with practical experiences can be droped, too.

\section{UVOD}

Začetek digitalnega modeliranja reliefa sega v 50-a leta, ko so v ZDA s pojmom digitalni model reliefa (DMR) prvič poimenovali enostaven računalniško podan niz tridimenzionalnih (3D) podatkov ( $X, Y$ in $Z$ koordinate prostorskih točk) o reliefu, ki je bil namenjen hitrejšemu, enostavnejšemu in avtomatiziranemu načrtovanju cestne infrastrukture. Od takrat lahko na tem področju, podobno kot na vseh ostalih, ki so vezani na informacijsko in računalniško tehnologijo, zasledimo živo raziskovalno in obenem

Mag. Mateja Rihteršič, Steletova 13, 61240 Kamnik. 
uporabniško usmerjeno dejavnost. $Z$ leti je pojem digitalni model reliefa postal sinonim za poljubne, digitalno zapisane nize $3 \mathrm{D}$ podatkov, širše pa vključuje tudi postopke za njihovo zajemanje, modeliranje, vzdrževanje in uporabo.

Poznamo več oblik DMR, ki jih klasificiramo na različne načine, npr.:

* glede na obliko podatkovne strukture oz. razporeditev prostorskih točk (trikotniški, gridni modeli,...),

* glede na velikost: lokalni (enonamenski, omejena površina) in regionalni (večnamenski, preko regij ali celih držav) ipd..

V preteklosti so se v praksi uveljavili predvsem lokalni DMR v obliki pravilnega kvadratnega grida, medtem ko $v$ zadnjih letih, zaradi višjih sposobnosti računalnikov, vedno pogosteje uporabljamo poljubne trikotniške modele. Za trikotniške in gridne modele reliefa so značilne številne prednosti, kakor tudi slabosti (glej Rihtaršič/Fras 1991). Glede na spekter produktov in aplikacij, ki jih digitalni model reliefa podpira, nobena izmed omenjenih podatkovnih struktur ni popolna, zato posvečamo iskanju najprimernejšega modela še vedno veliko pozornosti. Poleg tega so v zadnjih letih postali praktično uporabni tudi GIS-i, v okviru katerih DMR najpogosteje predstavlja eno izmed osnovnih informacijskih plasti, kar pogojuje obravnavanje DMR-ja (regionalni nivo) $z$ drugega zornega kota.

Sodobni regionalni DMR niso enostavni podatkovni nizi (datoteke) prostorskih točk, podanih s 3 koordinatami v ustreznem koordinatnem sistemu, temveč prave (relacijske) podatkovne baze (baza digitalnih podatkov reliefa

- BDPR), za katere so značilni:

- položaj poljubno razporejenih (razsutih) prostorskih točk je podan skupno z opisnimi podatki (atributi), med katerimi je najbolj pomemben pomen, s katerim popišemo posamezne reliefne oblike,

- glede na pomen lahko $\mathrm{v}$ nadaljnjih korakih modeliranja uporabimo različne algoritme in $s$ tem izdelamo kvalitetnejše modele zemeljske površine,

- shranjeni so originalni (zajeti) podatki, s čimer ohranimo natančnost in obenem omogočimo konstruiranje trikotniških ter gridnih modelov in hitro pretvorbo med obema strukturama,

- slonijo na standariziranih DBMS (ORACLE, INFORMIX,...), kar zagotavlja njihovo neposredno povezljivost $\mathrm{v}$ širši GIS,

- BDPR lahko predstavlja samostojen specialen GIS za relief in omogoča izvajanje poljubnih geografskih analiz in standardnih poizvedovanj, ki so neposredno vezana na relief.

Za splošne in regionalne BDPR, ki jih že vzpostavljamo $z$ namenom vključitve v GIS, so značilne vse lastnosti (problemi) topografskih/geografskih podatkovnih baz (velika količina grafičnih in numeričnih podatkov, različni tipi podatkov, vzdrževanost, širok spekter nalog in uporabnikov,...). Temu moramo, poleg podatkovne strukture, prilagoditi ostale korake dela od: 
- zajemanja podatkov,

- polnjenja in nastavitve osnovne in kasneje izvedene podatkovne baze,

- modeliranja podatkovne baze,

- vzdrževanja in arhiviranja podatkovne baze,

- kontrol posameznih korakov dela do

- eventualne vključitve vzpostavljene podatkovne baze v GIS.

\section{ZAJEMANJE PODATKOV}

Glede natančnosti, hitrosti in ekonomičnosti je za nastavitev lokalnih BDPR najprimernejši fotogrametrični composite sampling (CS) postopek. Kot rezultat dobimo model reliefa, ki temelji na polpravilni hierarhični podatkovni strukturi (trikotno- kvadratni zgoščujoči grid - TQN), ki je neposredno povezljiv $\mathrm{z}$ nekaterimi GIS programskimi orodji in $\mathrm{v}$ skladu $\mathrm{z}$ najvišjimi kakovostnimi kriteriji.

Ker je delo vezano na večje število sodobnih analitičnih sistemov, uveljavljeno programsko opremo (HIFI 88, PROSA, SCOP) in izurjene operaterje, za nastavitev regionalnih BDPR postopek ni ekonomsko in časovno opravičljiv. Tudi če ne upoštevamo časa in stroškov, ki jih potrebujemo za uvajanje ustreznih fotogrametričnih sistemov in izobraževanje kadrov pri nas, so ne samo CS, ampak tudi ostali natančnejši fotogrametrični postopki zajemanja podatkov primerni le za nastavitev lokalnih in vzdrževanje že obstoječih BDPR.

Poleg fotogrametričnih postopkov nimamo veliko izbire: terenska merjenja so predraga in prezamudna, postopki, ki temeljijo na obdelavi satelitskih slik, pa zaenkrat premalo natančni (takšne baze so primerne za topografsko kartiranje največ do merila 1:25000). Dragim in časovno zamudnim meritvám se lahko izognemo le s pretvorbo obstoječih in dovolj kvalitetnih analognih podatkov $v$ digitalno obliko. Pri tem lahko kot osnovne ali dodatne vire podatkov uporabimo karte in načrte $\mathrm{v}$ velikih merilih, aeroin ortofoto posnetke, rezultate terenskih meritev, podatke o položaju temeljnih geodetskih točk ipd.. Slovenija je ena izmed redkih dežel, ki je v celoti pokrita s temeljnimi topografskimi načrti $v$ merilih $1: 5000$ in 10000 (TTN5/10), ki so razmeroma kvalitetno izdelani in vzdrževani (fotogrametrični postopki). Z analogno/digitalno (A/D) pretvorbo vsebine oleat reliefa (izohipse, višinske točke, značilne reliefne oblike) lahko zajamemo večino podatkov, ki jih potrebujemo za nastavitev regionalne BDPR. Glede na veliko količino podatkov (izohipse) je skaniranje $\mathrm{z}$ naknadnimi postopki rastrsko/vektorske pretvorbe (R/V) podatkov danes najhitrejši, poceni (ugodna cena strojne in programske opreme) in obenem dovolj natančen postopek dela.

Topografske karte/načrti vsebujejo že izvedene podatke, ki so dodatno obremenjeni s številnimi pogreški (kartografski vzroki, subjektivni človeški faktor, neredno vzdrževanje ipd.), zato nas nastavitev BDPR na osnovi njihove $A / D$ pretvorbe $v$ prvem trenutku na more navdušiti. Primernost 
TTN 5/10 kot osnovnega vira podatkov, ki so potrebni za nastavitev regionalne BDPR lahko utemeljimo $z$ naslednjim (tuje izkušnje, raziskave doma):

- sodobni postopki A/D pretvorbe kart $z$ naknadnimi postopki obdelave rastrskih slik omogočajo zajem podatkov, katerih zanesljivost leži v rangu originalnih grafičnih predlog,

- zanesljivost vzpostavljenih BDPR je pri enakem merilu kart in aeroposnetkov približno enaka, hitrost in ekonomičnost postopkov, ki temeljijo na zajemanju podatkov s kart, pa neprimerno višja od fotogrametričnih postopkov,

- s podatkovno bazo, katere zanesljivost leži v rangu merila 1:5000, zadovoljimo potrebe širokega kroga uporabnikov in omogočimo izvajanje poljubnih aplikacij $v$ merilih med 1:5000 in 1:25000 (v manjših merilih lahko uporabimo satelitske slike),

- podatki so dovolj zanesljivi za modeliranje izvedenega gridnega modela $z$ velikostjo osnovne celice do $25 \mathrm{~m} * 25 \mathrm{~m}$ (natančnost), kar zadostuje za izdelavo ortofoto posnetkov velikih meril in širokega spektra kartografskih aplikacij,

- glede na namen, zanesljivost in natančnost podatkov se relief tekom časa skorajda ne spreminja, zato (eventualno) neredno vzdrževanje topografskih načrtov ne pogojuje generalno slabih ali neaktualnih podatkovnih baz,

- z vključitvijo dodatnih podatkov (npr. koordinate točk geodetske mreže) in pravilnim interpretiranjem njihovega pomena (oblikovnice) ali algoritmov za avtomatsko razpoznavanje značilnih oblik reliefa lahko zanesljivost zajetih podatkov zelo povečamo, kar nam posredno omogoča vzpostavitev natančnejše podatkovne baze in izvajanje aplikacij $v$ večjih merilih.

V sklopu nastavitve BDPR predstavlja zajemanje podatkov najbolj naporen, zamuden in zapleten korak. Le s pravilnim in pazljivim zajemanjem podatkov lahko dosežemo željeni nivo zanesljivosti podatkovne baze, ki je omejen $\mathrm{z}$ zanesljivostjo in merilom virov podatkov. Zajemanje podatkov, ki temelji na skaniranih topografskih kartah sestavljajo naslednji osnovni koraki:

- pripravljalna dela: izbira, ocena kvalitete in priprava grafičnih virov podatkov na skaniranje,

- analogno/digitalna (A/D) pretvorba (skaniranje) topografskih kart oz. oleat reliefa,

- editiranje rastrske slike oz. priprava za vektorizacijo,

- rastrsko/vektorska (R/V) pretvorba (vektorizacija) in zajemanje točk vzdolž vektoriziranih izohips,

- editiranje in obdelava vektorske slike,

- zajem višinskih točk (kote terena) (head-up digitalizacija),

- dodatne kontrole dela.

Zanesljivejšo (in realnejšo) BDPR lahko vzpostavimo, če vključimo še: 
- klasificiranje, razpoznavanje, A/D pretvorbo (ročno ali avtomatsko z naknadno head up digitalizacijo) in določitev višinskih komponent (posebni algoritmi) o značilnih reliefnih oblikah, ki so na topografskih kartah podane planimetrično,

- podatke o obstoječih trigonometričnih točkah,

- ostale podatke o obliki zemeljske površine (infrastrukturno omrežje, hidrologija,...).

\section{PODATKOVNA BAZA}

Ustrezno zasnovana BDPR je predpogoj za izpolnitev kvalitativnih in kvantitativnih zahtev, nemoteno in hitro zajemanje potrebnih (in samo potrebnih) podatkov, njihovo sočasno polnjenje $v$ podatkovno bazo in njeno nadaljnjo uporabnost. Vzpostavitev BDPR zajema:

- izbira vsebine (pomen, razporeditev, gostota,...),

- oblikovanje podatkovne baze in specificiranje posameznih tipov oblik,

- kreiranje podatkovne baze in

- specificiranje tipov oblik in ostalih elementov zajemanja podatkov.

Kljub temu, da so bile baze digitalnih podatkov reliefa (tudi digitalni model reliefa, če gre le za enostavne podatkovne zapise) predmet številnih analiz natančnosti, je določitev njihove natančnosti in srednjih pogreškov še vedno zapleten in $\mathrm{v}$ praksi nepriljubljen korak dela. Zato se pri določanju najprimernejše gostote točk in kasnejših analizah kvalitete in uporabnosti baz digitalnih podatkov reliefa pogosteje poslužujemo izkustvenih kazalcev. Pri izbiri razporeditve in gostote točk regionalne BDPR upoštevamo njeno uporabnost oz. namen, kvalitativne zahteve najširšega kroga uporabnikov, nujnost njene vključitve v GIS ipd.. Gostoto točk nato prilagajamo še ostalim faktorjem, kot so razgibanost zemeljske površine, algoritmi za modeliranje, merilo virov podatkov (topografskih kart), kvaliteta A/D pretvorbe topografskih kart ipd..

Glede na podatke, ki jih lahko ponudimo uporabnikom, ločimo:

- osnovna regionalna BDPR je sestavljena iz neposredno zajetih razsutih točk (prostorske koordinate razsutih točk s pripadajočimi atributi o njihovem pomenu) in je osnova za modeliranje izvedenih podatkovnih baz in standardnih produktov ter aplikacij,

- izvedene BDPR so modelirane iz osnovne; najnatančnejši med njimi je trikotniški model (prostorsko omrežje nepravilnih trikotnikov - TIN), med uporabniki najbolj popularen pa gridni model (pravilen kvadraten grid poljubnih dimenzij).

Glede na pomen, ki pogojuje pravilno izbiro algoritmov v nadaljnjih korakih modeliranja, razdelimo točke osnovne baze $\mathrm{v}$ naslednje osnovne skupine: 
- točke, ki ležijo vzdolž izohips,

- poljubne razsute višinske točke,

- kritične točke (kote terena),

- točke, ki ležijo vzdolž značilnih reliefnih oblik (grebeni, prelomnice, padnice,...).

Slika 1: Vsebina BDPR.

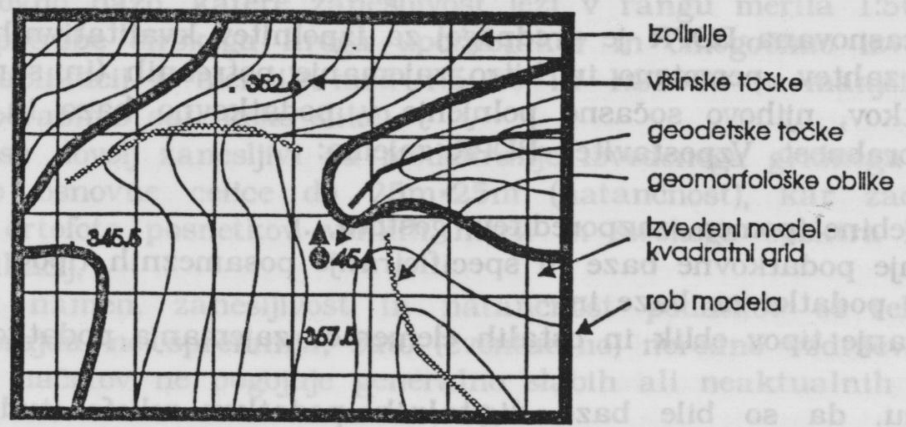

Slika 2: Upoštevanje različnih oblik.
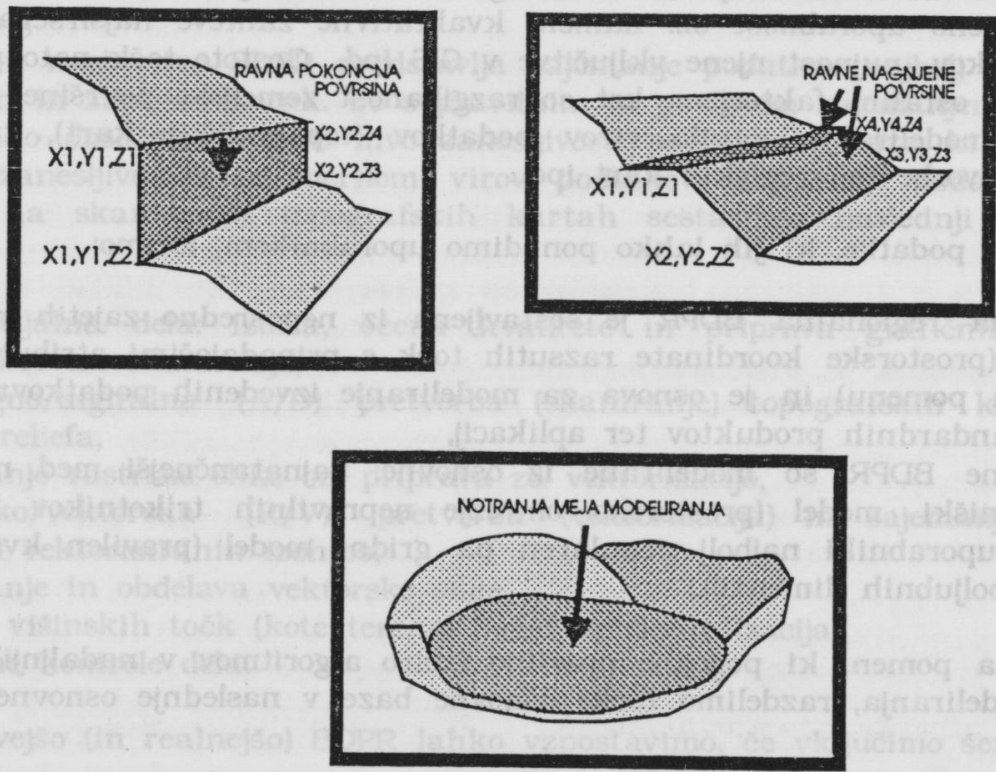
Pri samem modeliranju lahko glede na sposobnosti programske opreme upoštevamo oblike, kot so:

- točke, ki ležijo vzdolž večjih ravnih površin (prepadi, terase, jezera ipd.),

- točke, ki ponazarjajo zunanjo ali notranjo mejo modela,

- točke najvišje natančnosti oz. nepremične točke,

- gridne točke (dane ali izvedene) ipd..

Poleg tega moramo v BDPR voditi še splošne podatke, kot so datum vnosa, vir zajemanja podatkov, natančnost podatkov ipd..

Poseben problem predstavljajo poljubne točkovne, linijske in površinske reliefne oblike, ki so na topografskih kartah ponazorjene s kartografskimi pogojnimi znaki. Najpogosteje gre za oblike, ki jih zaradi njihove majhnosti ni mogoče metrično ponazoriti $v$ pravi velikosti, a imajo zaradi svojih posebnosti velik pomen na pravilen izgled modela reliefa. Na kartografske pogojne znake sta vezani predvsem dve vrsti problemov:

- Posamezni (točkovni) kartografski pogojni znaki so podani tudi $z$ nadmorsko višino, medtem ko so drugi (ploskovni - Alpe) izrazito "umetniški", slikovno nazorni, brez kakršnekoli povezave $z$ metriko. Poleg tega je tudi planimetrični položaj kartografskih pogojnih znakov mnogokrat nezanesljiv.

- Vizualne (slikovne) tehnike prikazovanja zemeljskega reliefa se že več kot 100 let skorajda niso spremenile, medtem ko smo $\mathrm{v}$ dobi računalnikov

Slika 3: Pomen kartografskih pogojnih znakov.

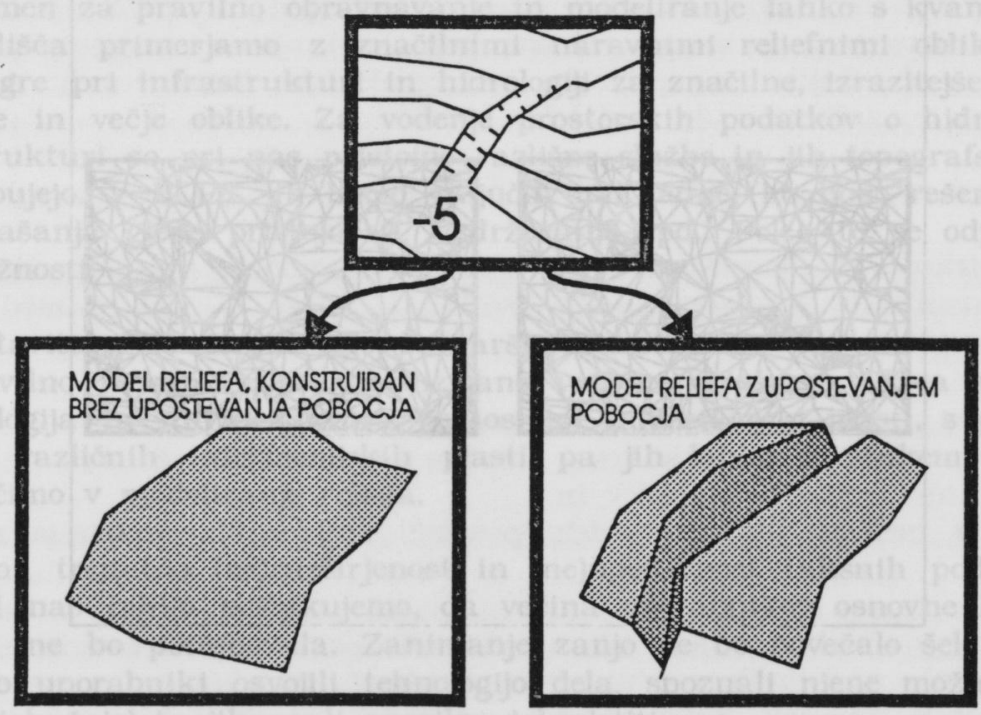


in informatike soočeni $\mathrm{z}$ novimi možnosti za prikazovanje zemeljske površine, drugačnimi načini uporabe teh prikazov in novimi nalogami, ki so vezane na prostor.

Kljub odprtemu vprašanju o dejanski uporabnosti (primernosti) obstoječega topografskega ključa pomena kartografskih pogojnih znakov ne smemo zanemariti. Kvalitetno BDPR (in ostalih informacijskih plasti $\mathrm{v}$ okviru GIS) lahko vzpostavimo le na osnovi podrobne analize potreb, novih metodologij dela, stanja pri nas in informiranja potencialnih uporabnikov prostorskih podatkovnih baz. Ker le-ta pri nas še ni bila realizirana, si lahko pomagamo na naslednji (začasni) način:

- pomembnejše reliefne oblike, ki so ponazorjene s kartografskimi pogojnimi znaki, vključimo v BDPR; njihove lastnosti pa shranimo $\mathrm{v}$ atributnem delu (uporabniške tabele),

- glede na velikost posamezne reliefne oblike klasificiramo v: - oblike, ki zaradi svoje velikosti $\mathrm{v}$ rangu merila $1: 5000$ na modeliranje ne vplivajo, vključimo v BDPR kot grafične elemente (pogojni znaki za izris); uporabniške tabele in bazo kreiramo tako, da lahko te oblike po želji in naročilu posameznikov tudi modeliramo, - večje oblike (prepadi, velike gramozne jame,...) so obvezni del modeliranja trikotniškega in gridnega modela in vseh ostalih aplikacij.

Slika 4: Trikotniška mreža brez in z upoštevanjem prelomnic.

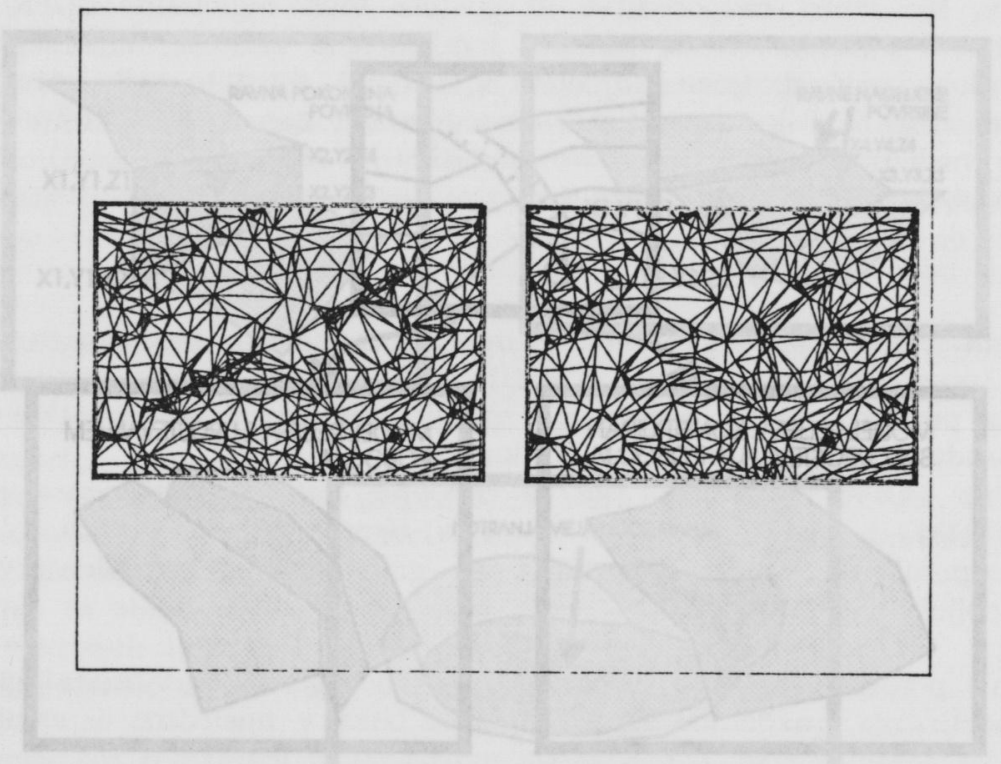


Slika 5: 3D pogled na gridni model, konstruiran z upoštevanjem prelomnic.

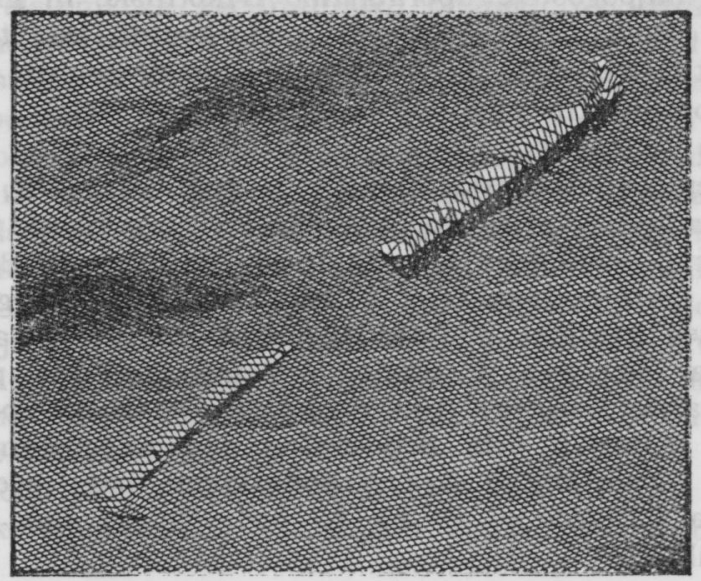

Kvalitetna BDPR mora vključevati tudi podatke o hidrologiji (jezera, omrežje rek) in infrastrukturnih objektih (ceste višjih kategorij, železnice). Njihov pomen za pravilno obravnavanje in modeliranje lahko s kvantitativnega stališča primerjamo $z$ značilnimi naravnimi reliefnimi oblikami, pri čemer gre pri infrastrukturi in hidrologiji za značilne, izrazitejše, pogosto pravilne in večje oblike. Za vodenje prostorskih podatkov o hidrologiji in infrastrukturi so pri nas pristojne različne službe in jih topografske karte ne vsebujejo. V BDPR jih bomo vključili naknadno, ko bodo rešena osnovna vprašanja glede pristojnosti, vzdrževanja ipd.. Poleg te se odpirata še dve možnosti:

- vzpostavitev BDP terena (glej Rihtaršič/Fras 1991),

- s pravilno rešeno in standardizirano vsebino splošnega GIS-a sta lahko hidrologija in infrastruktura samostojni informacijski plasti, s povezovanjem različnih informacijskih plasti pa jih lahko $v$ vsakem trenutku vključimo $\mathrm{v}$ modeliranje reliefa.

Glede na trenutno (ne)razširjenost in (ne)uporabnost takšnih podatkovnih baz pri nas lahko pričakujemo, da večina uporabnikov osnovne BDPR na začetku ne bo potrebovala. Zanimanje zanjo se bo povečalo šele čez čas, ko bodo uporabniki osvojili tehnologijo dela, spoznali njene možnosti (švicarske izkušnje) in jih znali pravilno izkoristiti. 
Izvedene regionalne BDPR so modelirane (interpolirane) iz osnovne. Predstavljajo prvo in najnatančnejšo aplikacijo osnovne podatkovne baze in so osnova za modeliranje nadaljnjih uporabniških aplikacij. Izvedene podatkovne baze temeljijo na enostavnejših podatkovnih strukturah in so namenjene uporabnikom, ki o modeliranju reliefa ne vedo veliko, ne razumejo pomena osnovnih podatkov in jih zato tudi ne znajo pravilno interpretirati. V ta namen najpogosteje uporabljamo trikotniške in gridne modele poljubnih dimenzij. Modeliranje izvedenih podatkovnih baz temelji na posebnih interpolacijskih metodah, ki so del cenovno dostopnih in $\mathrm{v}$ praksi razširjenih DMR-programskih modulov (rutinski korak dela).

$\mathrm{Ne}$ glede na omenjene vsebinske zahteve je tudi za BDPR, podobno kot za ostale baze podatkov o prostoru, najprimernejši relacijski podatkovni model, ki temelji na poljubnem izmed standariziranih RDBMS-jev (povezljivost). V našem primeru smo se odločili za razširjeni grafično-relacijski model, kjer so vsi grafični podatki shranjeni ločeno od alfa-numeričnega (relacijskega) dela. Ker sta $v$ okviru sistema oba dela podatkovne baze med seboj povezana, ima pri delu s podatkovno bazo uporabnik občutek, kot da $v$ obeh primerih dela neposredno nad relacijskimi tabelami. Ker sta kreiranje in vzpostavitev fizične podatkovne baze predmet obvladovanja uporabljenega RDBMS-ja, se na to področje na tem mestu ne bomo podrobneje spustili.

\section{MODELIRANJE PODATKOV}

V okviru sistema za nastavitev BDPR spadajo postopki modeliranja, takoj za zajemanjem podatkov in vzpostavitvijo osnovne baze, med pomembnejše korake. Pomen modeliranja stopi $v$ ospredje pri uporabi BDPR (nivo natančnosti, ohranitev semantičnega pomena podatkov), njenem vzdrževanju (spreminjanje in dopolnjevanje, pretvorba med modeli) in dopolnjevanju ter prilagajanju novim zahtevam že obstoječih modelov.

Modeliranje zajema naslednje (možne) postopke dela:

- konstruiranje tridimenzionalne (3D) ploskve - modela reliefa preko podatkov, shranjenih $\mathrm{v}$ osnovni podatkovni bazi (vmesni produkt med osnovno bazo in uporabniki),

- editiranje osnovne podatkovne baze ali izvedenih modelov,

- filtriranje osnovne podatkovne baze ali izvedenih modelov,

- generalizacija osnovne podatkovne baze ali izvedenih modelov,

- združevanje izvedenih modelov in

- pretvorbo med različnimi modeli (poseben primer konstruiranja modelov reliefa).

Konstruiranje modela reliefa oz. aproksimiranje zemeljske površine, kakor tudi izvajanje nadaljnjih produktov in aplikacij, temelji na ustreznem nizu matematičnih operacij (interpolacijske metode), ki jih lahko izvedemo na 
osnovi predhodno prestrukturiranih točk (trikotniški, gridni modeli) in vzpostavljene topologije med zajetimi podatki. Za izvedene modele velja:

- Nobeden izmed modelov ni popoln glede shranjevanja in obdelave podatkov ter reševanja različnih nalog (algoritmi). Ker ima na rezultate dela pri določenih nalogah izbira pravilnega modela odločilen vpliv, morajo biti današnji sistemi za računalniško podprto modeliranje reliefa prilagodljivi in omogočati hitro in enostavno pretvorbo med modeli različnih podatkovnih struktur. To je mogoče le, če razpolagamo tudi $z$ osnovno BDPR (zajeti podatki).

- Nobena interpolacijska metoda ni popolna; kvaliteta modela je omejena s porazdelitvijo in gostoto vhodnih podatkov, dani nivo lahko $z$ izbiro ustrezne interpolacijske metode samo ohranimo. Interpolacijski algoritem, ki je učinkovit na gladkem terenu, lahko na zelo razgibanem terenu popolnoma odpove. Zato moramo izbiro interpolacijske metode prilagoditi obliki reliefa, ki je spremenljiva, neponovljiva in je ne moremo matematično enolično določiti. Poleg tega moramo upoštevati tudi količino podatkov, saj so globalne interpolacijske metode pri veliki količini podatkov najpogosteje izredno nezanesljive.

- Sodobni interpolacijski algoritmi vključujejo razumevanje in pravilno interpretiranje tako geometričnih kot danih semantičnih informacij.

Zaradi zapletene podatkovne strukture in vezanosti na sposobnejšo računalniško opremo (algoritmi, spomin, čas) so se trikotniški modeli v praksi uveljavili šele $\mathrm{v}$ zadnjih nekaj letih. Osnovna slabost trikotniških modelov je zapletena struktura, vendar se, glede na kvaliteto aproksimiranega modela, gridni modeli ne morejo primerjati $z$ njimi. V sklopu zasnovane BDPR imajo trikotniški modeli dvojen pomen, saj so lahko osnova za izvajanje standardnih produktov in aplikacij, $\mathbf{k i}$ so vezani na relief ali ostale 3D površine ali konstruiranje gridnih modelov, pri čemer lahko uporabimo enostavnejše in zanesljivejše interpolacijske metode. Osnovni prednosti takšnega dela sta neodvisnost (prvi korak lahko izvedemo neodvisno od drugega) in lokalni značaj rezultirajočega gridnega modela, ki je prilagodljiv lokalnim spremembam.

V praksi uporabljamo le triangulacijske algoritme, ki združujejo numerično stabilnost, robustnost in učinkovitost. Številni (kvalitetni) algoritmi, ki so teoretično enolično definirani in temeljijo na obdelavi podatkovnih nizov $\mathrm{v}$ lokalni okolici obravnavane točke ter pravilih analitične geometrije, pri praktičnih problemih, zaradi vnaprej nepredvidenih (količina podatkov, oblika reliefa) in nepomembnih detajlov, pogosto odpovedo (Heller 1990).

Moderna, učinkovita, hitra in (zaenkrat) najboljša metoda konstruiranja trikotniških modelov je Delaunayeva triangulacija. Rezultat postopka je povezana prostorska mreža nepravilnih ravninskih (2D) trikotnikov, katerih oglišča ležijo $v$ točkah dane BDPR. Tudi Delaunayeva triangulacija je pomanjkljiva ali nepravilna (izguba informacij, nepravilno interpretiranje posameznih oblik), zato $\mathrm{v}$ praksi uporabljamo $\mathrm{z}$ geometričnimi in omejitve- 
nimi pogoji dopolnjene postopke. Sem spadajo številni lokalno izpopolnjeni algoritmi, ki so namenjeni reševanju posebnih problemov (združevanje ali vzdrževanje trikotniške mreže ipd, dodajanje novih točk, spreminjanje višine). Za naš primer so zanimive predvsem triangulacijske metode, prilagojene značaju izohips, ki vključujejo pravilno interpretiranje značilnih reliefnih oblik, lokalno preoblikovanje trikotnikov, razpoznavanje in naknadno upoštevanje prelomnic ipd..

Gridne modele konstruiramo s t.i. gridnimi interpolacijskimi metodami, ki so lahko lokalne ali globalne. Globalne interpolacijske metode so nenatančne in pri veliki količini podatkov nezanesljive, zato se $\mathrm{v}$ praksi pogosteje poslužujemo lokalnih metod. Glede na strukturo vhodnih podatkov ločimo dva pristopa modeliranja gridnih modelov:

- neposredni pristop: gridni model konstruiramo na osnovi osnovne BDPR; vhodni podatki so atributirane razsute prostorske točke in

- posredni pristop: gridni model konstruiramo preko vmesnega, najpogosteje trikotniškega modela reliefa.

Postopki posrednega konstruiranja gridnih modelov, ki so danes vedno bolj popularni, v splošnem temeljijo na istem izhodišču: izračunana višina iskane točke je odvisna od višin oglišč trikotnika, v katerem leži iskana točka. Med natančnejše postopke spada tudi trikotniško orientirana metoda bližnjih sosedov, pri kateri določimo koeficiente polinoma na osnovi višin oglišč in 1. in 2. odvodov, ki so odvisni od višin oglišč sosednjih trikotnikov. Če poteka preko posameznega trikotnika prelomnica, je prelomnica meja vplivnega območja interpolacijskega algoritma. Izboljšanje kvalitete, predvsem realnosti izvedenega modela, lahko (ob dani velikosti najmanjše gridne celice) naknadno dopolnimo $z$ upoštevanjem in vključitvijo značilnih reliefnih oblik zemeljske površine (npr. lokalno trikotniško omrežje).

V modeliranje izvedenih modelov prištevamo tudi naloge, ki jih izvajamo $z$ namenom izboljšave njihove kvalitete, odpravljanja pogreškov in vzdrževanja, kot so:

- filtriranje (glajenje, odstranjevanje točk - enaka kvaliteta modela, manjša količina podatkov),

- izboljševanje (poudarjanje detajlov oz. značilnih reliefnih oblik) in

- editiranje izvedenih modelov reliefa.

Postopki filtriranja modelov reliefa temeljijo na podobnih načelih kot digitalni nizkopasovni in visokopasovni filtri, ki jih poznamo s področja obdelave digitalnih slik. Tudi filtriranje modelov reliefa lahko izvedemo $v$ dveh območjih - ploskovnem in frekvenčnem (konvolucija Fourierjeve transformacije). S pomočjo nizkopasovnih filtrov model reliefa gladimo, t.j. odstranjujemo posamezne nepomembne, odvečne ali nepravilne detajle. Rezultirajoči model je gladkejši, brez prekinitev, lukenj ipd.. Izboljševanje modela je poudarjanje detajlov in značilnih reliefnih oblik. Temelji na visokopasovnih 
filtrih. Postopek je smiseln le pri trikotniških modelih, medtem ko gridne modele redko izboljšujemo. Filtriranje $v$ ožjem pomenu je odstranjevanje odvečnih (neredundantnih) točk. V praksi v ta namen najpogosteje uporabljamo:

- že uveljavljene postopke za redukcijo odvečnih vmesnih točk (dopustno kotno odstopanje, ohranjanje enakih razdalj,...),

- ustrezno prilagojene digitalne filtre in

- posebne algoritme, ki temeljijo na trikotniški podatkovni strukturi in danem dopustnem vertikalnem ( $Z$ koordinata) odstopanju.

Pri editiranju modelov reliefa uporabljamo posebne editorje, ki so prilagojeni lastnostim modelov reliefa ( $3 \mathrm{D}$ prostor) in omogočajo interaktivno iskanje in spreminjanje posameznih elementov, ki so del BDPR in izvedenih modelov. Med osnovne funkcije takšnih editorjev spadajo: povezovanje, brisanje, dodajanje, spreminjanje višine, spreminjanje atributa in povratna kontrolna povezava med uporabnikom in sistemom.

Poseben primer modeliranja: generalizacija. Pri generalizaciji BDPR se držimo splošnih načel kartografske generalizacije, ki jih moramo prilagoditi posebnostim ( $3 \mathrm{D}$ prostor) in namenu BDPR. Ker so vsi podatki že dani $v$ digitalni obliki, se vprašanju o uporabnosti in učinkovitosti avtomatske generalizacije ne moremo izogniti.

Z avtomatsko generalizacijo lahko rešimo vrsto problemov, ki so vezani na GIS-e, njihovo večnivojsko uporabnost (državni/lokalni nivo) in bazo digitalnega modela reliefa kot eno izmed informacijskih plasti GIS-a. Idealno gledano - avtomatska generalizacija je osnova za izvajanje aplikacij na vseh nivojih. To pomeni, da $z$ eno in eno samo BDPR zadovoljimo vse uporabnike in omogočimo izvajanje vseh nalog. Čeprav nekateri proizvajalci sodobnih DMR/GIS programskih orodij že napovedujejo izdelavo modula za avtomatsko generalizacijo, v bližnji bodočnosti ne moremo pričakovati celovite in popolnoma avtomatske rešitve tega problema (vsi problemi ročne generalizacije s področja klasične kartografije so $v$ tem primeru transformirani v 3D prostor!). Ločimo:

- generalizacijo osnovne BDPR in

- generalizacijo izvedenih podatkovnih baz, t.j. trikotniških in gridnih modelov.

Glede na stopnjo generalizacije, merilo, namen in uporabnost rezultatov so postopki generalizacije osnovne BDPR omejeni na selekcijo oz. izbiro pomembnih točk in redukcijo oz. odstranjevanje odvečnih točk. Ker se lahko $z$ različnimi interpolacijskimi metodami in različno gostoto točk $v$ izvedenih modelih prilagajamo zahtevam po različni natančnosti, generalizacija osnovne BDPR (razsutih točk) ne spada med običajne in pogoste korake dela. 
Poznamo tudi več učinkovitih interaktivnih postopkov računalniško podprte generalizacije (polavtomatske) izvedenih modelov reliefa, npr.:

- generalizacija gridnih modelov temelji na tehnologiji glajenja digitalnih slik (Loon 1978, Zoraster 1984), generalizacija trikotniških modelov $\mathrm{Z}$ odstranjevanjem nepomembnih točk (Gottschalk 1972),

- generalizacija, ki temelji na strukturnih linijah ipd..

Našteti postopki vseh problemov generalizacije ne rešujejo $v$ popolnosti. Tudi kvaliteta rezultatov je spremenljiva in odvisna od razgibanosti zemeljske površine, razporeditve vhodnih podatkov, merila dela in stopnje generalizacije. Postopek avtomatske generalizacije je zajet $\mathrm{v}$ posplošenem modelu, ki združuje načela umetne inteligence, razumevanja slik in kartografske generalizacije, prilagojene lastnostim modelov reliefa (3D prostor). Model združuje in povezuje niz (soodvisnih) postopkov in temelji na naslednjih načelih:

- postopek generalizacije mora biti prilagodljiv različnim tipom reliefa, različnim merilom in različnemu namenu rezultatov,

- vključevati mora mehanizme (operatorje) za avtomatsko razpoznavanje strukture reliefa,

- podpirati mora kartografske in statistične postopke generalizacije,

- vključevati mora cenzuse generalizacije posameznih zemeljskih oblik (najmanjši element, eliminacija, združevanje itd.),

- izbira in kombinacija najprimernejših postopkov mora temeljiti na predhodno razpoznani strukturi reliefa.

Model združuje in medsebojno prilagaja tri osnovne postopke avtomatske generalizacije:

- globalno filtriranje (obdelava digitalnih slik) je primerno pri velikih spremembah meril in gladkem reliefu,

- selektivno filtriranje (iterativna procedura za avtomatsko razpoznavanje značilnih reliefnih oblik na osnovi višinskih razlik in danega praga) lahko uporabimo tudi na zelo razgibanem terenu, vendar le do določene stopnje generalizacije,

- heuristično generalizacijo (človek), ki temelji na generaliziranju strukturnih linij in je vezana na predhodni korak njihovega razpoznavanja, uporabimo na področjih, kjer gornja postopka ne podajata zadovoljivih rezultatov (interaktivno!).

Tako zasnovano avtomatsko generalizacijo lahko izvedemo $v$ naslednjih petih korakih: razpoznavanje strukture, razpoznavanje postopkov dela, modeliranje procesa, izvajanje procesa in prikaz rezultatov (Weibel 1991).

Če razpolagamo $z$ osnovno BDPR, ki vsebuje ustrezno atributirane razsute prostorske točke, se lahko pri gridnem modelu opisanemu problemu (avtomatske) generalizacije izognemo. Eno izmed načel $v$ okviru digitalnega 
modeliranja reliefa je: pri danih podatkih se lahko zahtevam po različni natančnosti prilagajamo $z$ gridi različnih dimenzij. To pomeni, da lahko $z$ gridom večjih dimenzij na osnovi natančnih podatkov izvedemo manj natančen in generaliziran model. Ker je slepo povečevanje velikosti osnovne gridne celice povezano $z$ izgubo pomembnih informacij, kar lahko pokvari realnost in pravilnost rezultirajočega modela, predlagamo naslednji postopek:

- zahtevani natančnosti se prilagajamo s pravilno izbiro velikosti osnovne gridne celice, vendar

- pri konstruiranju gridne mreže (še vedno posredno preko trikotniškega modela) obvezno uporabimo bikubično ali natančnejše interpolacijske metode,

- vključimo vse geodetske in digitalizirane kritične točke, vključno $z$ njihovim pomenom, kot nepremične točke največje natančnosti, t.j. ploskev reliefnega modela mora preko teh točk,

- vključimo in pravilno upoštevamo tudi vse značilne linijske reliefne oblike.

Prednost opisanega in popolnoma avtomatskega postopka generalizacije so enostavnost, hitrost in takojšna izvedljivost (ne potrebujemo posebne programske opreme).

\section{ZAKLJUČEK}

Omenjena izhodišča, postopki in problemi, ki se jim zaradi omejitve s prostorom ne moremo detajlneje posvetiti, so bila osnova za vzpostavitev testnega modela BDPR. Pri tem smo uporabili:

- TTN 5 (relief) kot osnovni vir podatkov (skaniranje izohips, head-up digitaliziranje višinskih točk in značilnih reliefnih oblik),

- ČB skaner, ločljivost skaniranja 300 dpi (kvaliteta izohips),

- standardni RDBMS (INFORMIX) (glej shemo podatkovne baze),

- standardni programski paket za modeliranje podatkovne baze.

Vzpostavljena BDPR izpolnjuje osnovne tri izmed zastavljenih ciljev:

- nivo njene uporabnosti in zanesljivosti leži $v$ rangu grafične natančnosti merila 1:5000,

- "inteligentni" značaj in

- dejanska vzpostavitev podatkovne baze in njena neposredna povezljivost v GIS.

Natančnosti podatkovne baze nismo posvetili posebne pozornosti, saj jo zagotovljajo:

- izbrani postopki A/D pretvorbe $z$ naknadno obdelavo rastrskih podatkov,

- kvalitetni instrumenti in 
Slika 6: Shema vzpostauljene podatkoune baze.

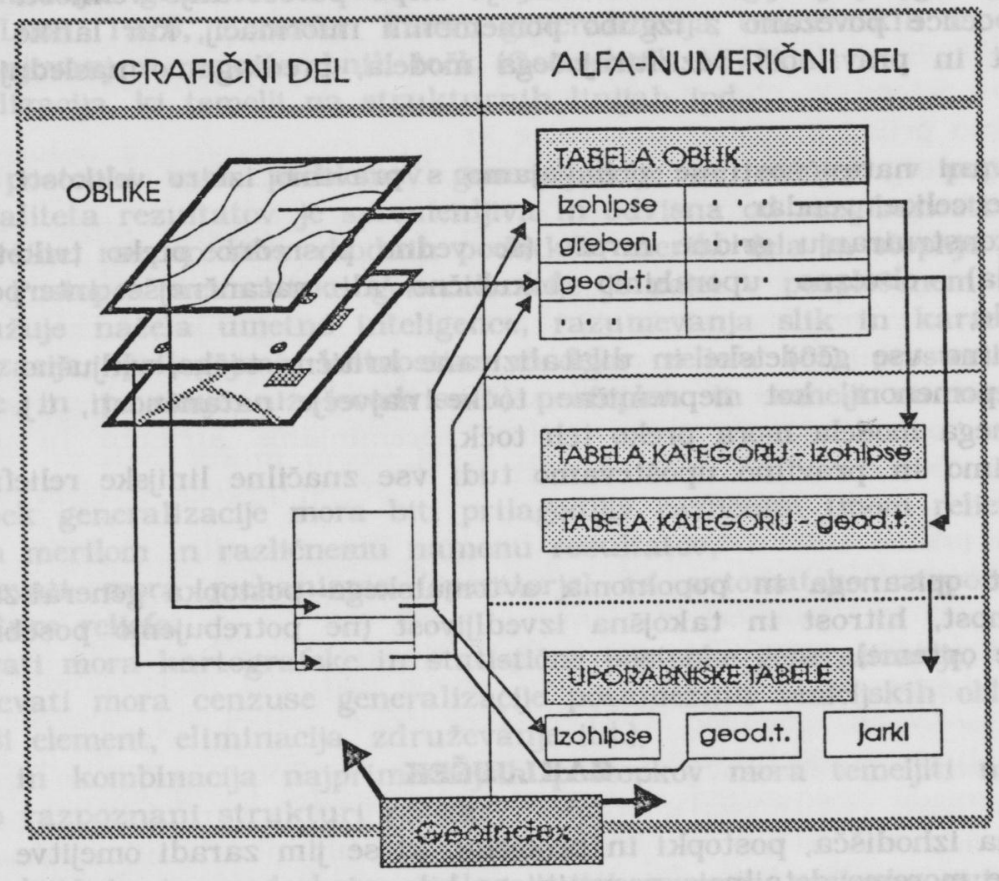

- pazljivo izvajanje ročnih postopkov $z$ ustreznimi kontrolami dela (odstranitev grobih pogreškov),

- uporabljena metodologija modeliranja (zajemanje in upoštevanje značilnih reliefnih oblik, projiciranje $2 \mathrm{D}$ oblik $\mathrm{v} 3 \mathrm{D}$ prostor) ipd..

Vzpostavitev podatkovne-baze in strukturiranje podatkov sta nalogi, pri katerih si nismo mogli pomagati s tujimi izkušnjami. Osnovni vodili sta nam bili dane zahteve (povezljivost $v$ GIS) in standardni RDBMS. $Z$ rezultatom smo več kot zadovoljni: vzpostavili smo relacijsko podatkovno bazo, ki je neposredno povezljiva $v$ GIS in obenem izpolnili dane vsebinske zahteve. Kot logično posledico danih izhodišč smo vzpostavili topologijo, ki na področju (samo) digitalnega modeliranja reliefa ni običajna. Vzporedno s tem smo odprli možnost njene uporabe, ki je vnaprej nismo načrtovali kot samostojna informacijska plast specialnega GIS-a za relief omogoča, poleg standardnih DMR produktov, izvajanje geografskih aplikacij, analiz in poizvedovanj, ki so neposredno vezana na relief.

Med pomembnejša izhodišča spada tudi čas, ki ga potrebujemo za vzpostavitev sistema, šlanje primernih kadrov in realizacijo projekta preko cele 
države: $z$ razpoložljivim orodjem ( 1 delovna postaja) in dvema operaterjema, ki delata $v$ dveh izmenah, lahko delo končamo v 3 letih. Ker lahko časovno najzamudnejše operacije brez sprememb, dodatnega izobraževanja kadrov in tudi brez nepotrebnega povečanja časa izvedemo na bolj razširjenih PC računalnikih, lahko BDPR vzpostavimo tudi hitreje.

$\mathrm{Na}$ koncu bomo preleteli osnovne značilnosti (naše praktične izkušnje) posameznih korakov dela. Možnosti in uporabnost postopkov skaniranja $z$ naknadnimi koraki obdelave rastrskih slik lahko strnemo v:

- za zajemanje velike količine grafičnih podatkov je skaniranje že danes najprimernejši postopek dela;

- avtomatska vektorizacija je že izvedljiva, vendar so rezultati najpogosteje zelo slabi; zato se $\mathrm{v}$ praksi poslužujemo programskih modulov za interaktivno vektorizacijo, ki so prilagojeni značaju obravnavanih grafičnih elementov (izohipse);

- glede na zapletenost problematike programskih modulov ni smiselno razvijati doma; poznamo vrsto preizkušenih, kvalitetnih in cenovno ugodnih paketov, ki rešujejo večino spremljajočih problemov;

- vseh korakov dela ne moremo vnaprej enolično predvideti, probleme moramo reševati sproti;

- zajemanje podatkov je časovno najbolj obsežen postopek dela, vezan na veliko količino napornega operaterjevega dela (editiranje).

Današnji sistemi podatkovnih baz pogojujejo:

- izbiro poljubnega izmed standariziranih RDBMS-ov, ki so med seboj povezljivi in jih lahko vzpostavimo na računalnikih različnih zmogljivosti, pri čemer nismo vezani na aplikativno programsko opremo (standardi),

- z operativnega stališča je za BDPR najboljši razširjeni (grafično-relacijski) podatkovni model,

- ustrezno zasnovana baza je povezljiva s standardnimi GIS orodji in lahko nastopa kot specialni GIS,

- objektno-orientirani sistemi operativno še niso uporabni, lahko jih uporabimo kot nadgradnjo na nižjih nivojih oz. dograditvi osnovne podatkovne baze $v$ specialen GIS,

- pravilno strukturiranje podatkov in polnitev podatkovnega modela sta predpogoj za kvaliteto celotnega sistema, vzpostavljene podatkovne baze in stopnjo njene uporabnosti.

Glede modeliranja podatkov $v$ sklopu celotnega sistema lahko izpostavimo:

- osnovna regionalna baza razsutih prostorskih točk je osnova za konstruiranje poljubnih izvedenih modelov (trikotniški in gridni) in vseh nadaljnjih aplikacij,

- idealna podatkovna struktura modela reliefa ne obstoja, zato sodobni sistemi vključujejo možnost pretvorbe med posameznimi podatkovnimi 
modeli; hitra in kvalitetna pretvorba je mogoča le, če razpolagamo $z$ osnovno BDPR,

- kvaliteta modelov je omejena s kvaliteto osnovne baze in odvisna od algoritmov modeliranja; s pravilnim interpretiranjem reliefnih oblik lahko dani rang samo izpolnimo ali pokvarimo - preseči ga ne moremo;

- s transformacijo značilnih reliefnih oblik, ki so na topografskih kartah podane samo planimetrično, v 3D prostor in ponovnim konstruiranjem modelov reliefa lahko natančnost, predvsem pa realnost in izgled rezultirajočih modelov zelo povečamo,

- zaradi hitrosti modeliranja trikotniških in gridnih modelov ni potrebno hraniti $\mathrm{v}$ podatkovni bazi ( $\mathrm{v}$ našem primeru imamo posreden vstop tudi $v$ podatkovno bazo, pri čemer uporabnik ne ve, da ne dela neposredno nad bazo) ipd..

\section{UPORABNOST}

Ob dani natančnosti prepuščamo uporabo BDPR in izvajanje konkretnih aplikacij posameznikom. Izpostavili bomo le lastnosti, ki predstavljata novost. Vzpostavljena BDPR je:

- neposredno povezljiva $\mathrm{v}$ splošen GIS,

- lahko samostojna (in edina) informacijska plast specialnega GIS-a in obenem platforma za izgradnjo drugih specialnih GIS- ov.

Neposredno povezljivost BDPR v splošni GIS zagotavljajo:

- relacijska podatkovna baza,

- uporabljeni in standarizirani RDBMS (INFORMIX), ki je neposredno povezljiv $\mathrm{z}$ ostalimi standardnimi RDBMS-i,

- neodvisnost podatkovne baze od strojne in programske opreme in

- hierarhična zasnova projekta in sheme, ki $\mathrm{v}$ okviru podatkovne baze predstavljata vrh drevesa; po potrebi ju lahko prestavimo na nižje nivoje in jima priredimo nove veje (druge informacijske plasti) - novi vrh drevesa je $v$ tem primeru GIS (podobno velja za specialne GIS-e).

BDPR lahko nastopa kot samostojna informacijska plast specialnega GIS-a (GIS za relief), kar omogočajo pravilna zasnova projekta, sheme in struktura shranjenih podatkov. Na osnovi vzpostavljene topologije in vseh elementov, ki jih hranimo $\mathrm{v}$ sistemu, lahko izvajamo osnovne geografske analize, kreiramo vplivna območja, izvajamo nekatera (na relief vezana) vprašanja in poizvedovanja ipd.:

- koliko vrtač, ki so globje od $5 \mathrm{~m}$, leži na izbranem omejenem območju,

- poišči vse prelomnice, ki so ponazorjene $s$ kartografskim pogojnim znakom,

- poišči območja, kjer je nagib večji od $15 \%$ ipd..

Na osnovi specifikacij (enostavni grafični simboli za izris shranjenih oblik) lahko izrišemo ustrezne kartografske prikaze. $Z$ dodatnim kreiranjem knji- 
žnice simbolov lahko vključimo tudi zapletenejše kartografske pogojne znake .... . Možnosti je veliko.

Odprta so ostala nekatera vprašanja, ki so $v$ tem trenutku izven našega dosega, a imajo na uspešno realizacijo projekta na regionalnem nivoju lahko odločilen vpliv. Glede na značaj jih lahko strnemo v štiri skupine:

- vsebinske zahteve: vprašanje kartografskih pogojnih znakov, hidrologije in infrastrukture ter smiselnost nastavitve baze digitalnih podatkov terena in ne reliefa,

- tehnološki problemi, ki so vezani na izpopolnitev (avtomatizacijo) časovno zamudnih interaktivnih postopkov dela (avtomatska vektorizacija, avtomatska generalizacija,...) in problem horizontalnega združevanja podatkovne baze,

- upravno-pravni problemi: pristojnosti, lastništvo, nadzor, vzdrževanje, sistem kontrole ipd.,

- problem ponudbe in uporabnosti BDPR.

Skratka - odprtih je še veliko problemov, ki jih moramo rešiti. Tehnologija dela se iz dneva $\mathrm{v}$ dan spreminja, zato lahko tudi na tem področju pričakujemo še veliko sprememb. Nepotrebnemu izgubljanju besed in številnim dogovarjanjem se lahko izognemo le s takojšnim delom (sistem smo vzpostavili, tehnologija je tu...), ki pa ni smiselno, če vzpostavljene BDPR ne bo nihče uporabljal. Prva naloga, ki nas že čaka, je izobraževanje posameznikov - vseh tistih, ki bazo digitalnega modela reliefa potrebujejo, a je ne znajo uporabljati ali imajo slabe izkušnje $z$ zastarelim modelom DMR 100 in ne poznajo možnosti, ki jih odpirajo sodobne baze digitalnih podatkov reliefa. 